Available online at www.ktu.edu.gh

International Journal of Technology and Management Research 4 (2019)

International Journal

\title{
Impact of Regulated Biogas Market Structure on Benefits of Biogas in Ghana
}

\author{
Eric Fifi Ankamah ${ }^{1}$, Animpong M. A. $\mathrm{B}^{1}$., Ampomah-Benefo $\mathrm{K}^{1}$., Ferdinand Tornyie ${ }^{1}$ \\ ${ }^{1}$ Council for Scientific and Industrial Research - Institute of Industrial Research, P.O. Box 576, Legon, Ghana, \\ ${ }^{2}$ E-mail fifiankamab@yahoo.com
}

\begin{abstract}
Improved environmental management facilities provide social benefits to economic agents in Ghana. Biogas technology facility is one solution that offers societal gains. However, the maximization of social benefit in some cases depends on the structure of the market. The objective of this study was to examine loss in consumer surplus and gain in producer surplus, and if there was, deadweight loss relating to regulated biogas market structure in Ghana. The simple market models were fundamental tools in the economic surplus method used for the study. The results of the study showed that regulated monopoly although productive reduces societal gains and so inefficient compared with the free market. The regulated monopolist' producer gain was $13 \%$, but there was $37 \%$ and $41 \%$ loss to consumers and investors' NPV respectively. There was also a deadweight loss of US $\$ 18,140.00$. Market forces allow consumers to be future regulators of previously government regulated $2^{\text {nd }}$ and $3^{\text {rd }}$ degree discriminating monopoly. It is possible to avoid Market forces regulation in biogas diffusion when participants are reluctant to hike price.
\end{abstract}

Keywords: regulated biogas market; biogas market; economic surplus method; deadweight loss; consumer and producer surpluses

Citation: Eric Fifi Ankamah, Animpong, M. A. B, Ampomah-Benefo, K., Ferdinand Tornyie Impact of Regulated Biogas Market Structure on Benefits of Biogas in Ghana 2019; 4(1):35-49.

Received: January 2019

Accepted: April 2019 
1.0 Introduction

1.1 Background

Biogas is a waste-to-energy technology. A simple well-known biogas technology called anaerobic digestion produces gaseous fuel from biogas plant (Abbasi, et al., 2012). Technically, anaerobic digestion is a biochemical conversion, for energy production - whereby organic matter is transformed into energy by the action of microorganisms. This conversion process involves the breakdown of complex organic materials into simple compounds that can be absorbed and used as nutrients, usually by the microorganisms. New substances are also formed through anabolic processes. The microorganisms eventually use the nutrients to produce combustible biogas comprising mainly of $\mathrm{CH}_{4}(50-70 \%), \mathrm{CO}_{2}(30-45 \%)$, and nutrient-rich sludge (Wagner, et al.,2009; Herrmann, et al., 2016).

Bensah et al (2010) traced the history of biogas research and development (R\&D) and dissemination in Ghana. Bensah et al (2010) mentioned; locations of biogas plant, names of private and public companies involved in biogas construction and showed pictures of biogas facilities in Ghana. There are challenges in the biogas market in Ghana. The challenges in dissemination of biogas technology include; government support in favour of a firm or an agency in biogas business, high capital cost, longer periods for construction and highly specialized technical skills requirements etc.

A 'free' biogas market is the one in which suppliers and clients appear to freely participate in a (semicompetitive) market environment, though barriers exist. A regulated biogas market has different conditions to produce efficiently. In a situation where a supplier is offered governmental support or possesses the means or capabilities to overcome the other challenges and so it is able to control $25 \%$ or more of the market, the supplier is deemed to have regulatory monopoly power. Government as a re-distributor of income and wealth in an economy must address if any, distributional inefficiency of markets.

The neoclassical view of monopoly power is that monopoly incriminates power and abuse position. This hurts consumers because the monopolist will take part in consumer benefit. However, Stamate, (2011) argued that one fundamental law of economics provides that when the monopolist's prices go up, consumer demand goes down, due to reliance on a substitute for the monopolised good. Rothbard, (2004) and Stamate, (2009) argued that in markets where demand exists, people can sell goods on a contractual basis; 
therefore, there is no reason for incriminating such persons - in terms of the suggestion of reduction in social benefit.

This study is justified in finding out shifts or differences between consumer and producer benefits in free biogas market and regulatory monopoly market. Walekhwa (2010) evaluated the socio-economic viability of biogas production and utilization of the family sized digesters in Uganda. Ankamah et al (2017) demonstrated that effective and efficient biogas and biochar dissemination in faecal waste management produces commercially successful outcome in Ghana. They basically compared the profitability of two products or technologies using human waste as raw material. A distinguishing feature of this study is that it investigates economic outcomes from two market structures dealing in one same product.

According to Salerno, (2005) and Costea, (2006, pp.97) monopoly face the same market forces, like perfect competition firms who cannot hike prices and so there will be no (permanent) high profit for the monopolist too. In reality market segmentation by firms in some cases shift some consumer surplus into losses. Therefore, the study will be useful in understanding the reduced professional fees received by Council for Scientific and Industrial Research - Institute of Industrial Research (CSIR- IIR) as a sole or main contractor for most government biogas projects through the District, Municipal and Metropolitan Assemblies (DMMAs) from 2000 to 2015.

It is expected that the comparison in this study will bring out the loss or gain in consumer surplus and producer surplus respectively, and subsequent deadweight loss relating to regulated biogas diffusion in Ghana. Therefore, the objective of this study is to compare the benefits from regulated biogas market and 'free' biogas market, to highlight loss or gain in consumer surplus and producer surplus as well as deadweight loss in Ghana.

\subsection{Methodology}

Masters et al., (1996), suggested approaches including the economic/social surplus methods, the econometric methods, and the programming methods for economic assessment. Walekhwa (2010), used econometrics and cost-benefit analysis which predicted households' biogas adoption of $90.4 \%$ of the total observations. The economic surplus method fits cases where benefits are not known directly, and therefore it becomes prudent to use market information to compute direct benefits.

In this study, for the purposes of consistency and robustness, the Cost-Benefit Analysis (CBA) method and a set of data were used for both free biogas market and the regulated market computations. This avoided methodological differences affecting biogas benefit and therefore loss or gain in biogas benefit in this study 
was attributable to different market conditions. However, the most important feature of this study is the efficiency models that were sources of divergence, which were clearly indicated and measured.

Prior to the Cost-Benefit Analysis (CBA) the economic surplus approach quantified direct benefits through calculus integration. Studies that were based on markets mostly need demand, supply and price theoretic; which are foundations of the demand and supply functions. In other to determine market equilibrium the slope method was employed to derive values of important variables of the functions using quantity demanded, quantity supplied and price.

\subsection{Theoretical Models}

The models were essentially microeconomics equations for direct benefits computations. The integral calculus used to compute direct benefits usually termed as Consumer Surplus (CS) and Producer Surplus (PS) relating to both biogas market structures was specified as:

$\mathrm{CS}=\int_{0}^{Q} \mathrm{DQ} \mathrm{dQ}-\mathrm{Po} \mathrm{Qo}$

The Consumer surplus (CS) is the difference between the total amount that consumers are willing and able to pay for a good or service (indicated by the demand curve) and the total amount that they actually do pay (i.e. the market price).

PS $=$ Po Qo- $\int_{0}^{Q}$ SQ dQ

The Producer surplus (PS) is the difference between the actual price at which the producers sell their products and the price they expected to sell their product. It is the same as Economic Rent. Po is equilibrium price, Qo is the equilibrium quantity. DQ is different quantities of a good demanded, SQ is different quantities of a good supplied. Market models include demand and supply functions. The demand function can be stated as;

$Q d=a-d(Q)$

and the supply function is;

$Q s=-c+b(Q)$

In equilibrium $a-d(Q)=-c+b(Q)$

Where; the left hand side (LHS) a $-\mathrm{d}(\mathrm{Q})$ is the inverse demand function and the right-hand side $-\mathrm{c}+\mathrm{b}(\mathrm{Q})$ is the inverse supply function, $\mathrm{a}$ is a constant representing other demand determinants apart from own price, $\mathrm{d}$ is own price which determines changes in quantity demanded, $\mathrm{c}$ represents the determinants of supply excluding own price, $\mathrm{b}$ is own price which determines changes in quantity supplied. 
The cardinal departure that exhibited the major differences in the direct consumer surplus and producer surplus for 'free' biogas market and regulated market monopolist is that, whereas for the former production efficiency is a point where price is equal to marginal cost: $\mathrm{P}=\mathrm{MC}$, in the latter efficiency is at where marginal revenue is equal to marginal cost $\mathrm{MR}=\mathrm{MC}$. The values of important variables of the inverse functions were derived using the slope method $(\mathrm{P}=\mathrm{MQ}+\mathrm{C})$; where, $\mathrm{P}$ is the original price for both quantity supplied and quantity demanded, $\mathrm{M}$ is the change in price over the change in quantity demanded or quantity supplied. $\mathrm{Q}$ is the original quantity demanded or quantity supplied, $\mathrm{C}$ is the quantity to be determined if $\mathrm{P}, \mathrm{Q}, \mathrm{M}$ are put in the equation.

Economic viability indicators include Net Present Value (NPV), the Internal Rate of Return (IRR), the Benefit-Cost-Ratio (BCR) otherwise refer to as Profitability index (PI) and, payback period (Yiridoe et al., 2009 and Maredia et al., 2000). The payback period is the number of years taken to recoup the initial investment into the project. The Undiscounted Payback Period (UPBP) is Total Cost (TC) divided by annual profit (п) UPBP $=\mathrm{TC} / \Pi$. The basic notion of NPV is that present consumption yields more satisfaction than the same amount of consumption in the future.

$N P V=\sum_{t=1}^{n} \frac{B_{i}}{(1+r)^{i}}-C_{i}$

and Profitability index (PI) is evaluated with the formula below

$P I=\sum_{t=1}^{n} \frac{B_{i}}{(1+r)^{i}} / C_{t}$

where; $B_{i}=$ annual flow of benefit in time period $t ; n=$ the expected life of the project; $C_{i}=$ cash outlay, $r$ $=$ discount rate. In a single project, the rule is to accept the project if the sum of NPV flows positive (NPV $>0$ ). This implies that the rate of return on investment is higher than the discount rate used and is greater than the opportunity cost of capital used at the discount rate. When the NPV is negative (that is NPV less than zero $(\mathrm{NPV}<0)$ the project should be rejected.

There is a possibility of ranking an inefficient decision if NPV is solely used. The NPV measure of viability is an absolute value. In addition to NPV, a profitability index (PI) which provides a relative measure of an investment's desirability can be used in support of viability decision. BCR is the ratio of present value (PV) of the future flow of benefits to its initial cost. Accept projects with PI greater than one (1) as in this case. A zero NPV makes the investor indifferent, in which case other factors and benefits relating to the investments should be considered. One consideration for zero NPV is the IRR or $\left(\mathrm{r}^{*}\right)$. IRR is the derived discount rate from the stream of benefits that make the present value $(\mathrm{PV})$ equal to zero $-\mathrm{r}^{*}=\mathrm{PV}-\operatorname{cost}=$ 
0 NPV. The ${ }^{*}$ was set first by try and error (extrapolation) to get a low rate that gives high PV and the high rate that gave low PV.

$I R R=r^{*}=r h-\left[\frac{\left(r_{h}-r_{l}\right) h P V}{l P V}+h P V\right]$

where $\mathrm{rh}=$ high rate, $\mathrm{rl}=$ low rate, $\mathrm{hPV}=$ high Present Value, $1 \mathrm{PV}=$ low Present Value

The decision rule is that if the $r *$ is greater than $r$ (the predetermined rate) or the $r *$ of the best alternative then accept the project. IRR of zero NPV is the break-even point where biogas viability is sustainable, implying that any increase in the cost streams beyond the benefits leads to negative NPV, and that, the biogas system will start incurring losses.

\subsection{Empirical methods}

Fixed dome digesters disseminated in Ghana were mostly between 40 to $50 \mathrm{~m}^{3}$ and the ABRs were from 30 to $40 \mathrm{~m}^{3}$ capacity. Two exceptional digesters - a $200 \mathrm{~m}^{3}$ capacity and the other $800 \mathrm{~m}^{3}$ were observed at Ankaful Prison and Guinness Ghana Breweries Limited, Kumasi respectively. This study analysed the commonly adopted biogas projects of almost the same size digester of $40 \mathrm{~m}^{3}$ disseminated between 2000 and 2015 (15years).

The economic surplus approach needs less information which may not require sampling. The variables of the market data used were the quantity demanded, quantity supplied and price, which was first sourced from secondary documents. Bensah et al., (2010), reported that a survey by Kumasi Institute of Technology, Energy and Environment (KITE) found 100 fixed dome digesters disseminated (supplied) through-out Ghana.

Biogas dissemination is a specialized business by scientists and research commercialization officers who possessed the requisite experience. This study found the KITE survey result credible because an interview with all the ten (10) member team of supervising consultants from CSIR- IIR for the National Biogas Project provided price and a range between 90 to 110 facilities for the fixed dome digesters which on average gave approximately 100 plants, thus confirming the KITE's survey result.

The 100 digesters observation by the KITE survey were utilised in the adoption rate analysis. This meant that the entire population of biogas plants disseminated was captured in the adoption rate analysis. Adoption rate measures the goodness-of-fit of the independent variables in an adoption (supply) model. One adoption rate for technology is the Nagelkerke $R^{2}$ adoption rate (the lower rate being 69\%). 
Obviously, the 100 biogas plant supplied was less than demand for biogas digesters; as suggested by Ankamah et al (2017) that toilet facilities in Ghana were inadequacy and poor, and so this study equated the entire 100 plants population (not a sample) disseminated to the lower Nagelkerke $\mathrm{R}^{2}$ adoption rate of $69 \%$. Consequently, the market demand for the fixed dome biogas technology was estimated as;

- Quantity demanded = 145 plants at a price of GH\$ 68.89 each, and

- the KITE Quantity supplied was 100 at same price of GH\$68.89

The price was in thousands (000s) of cedis per unit of a biogas plant.

Data for the Anaerobic Baffled Reactors (ABR) which was mostly disseminated in the National Biogas Projects came from approved project proposals and signed project contracts documents which were also corroborated by the interview with all members of the CSIR- IIR supervising team directly involved in the National Biogas Project. The ABR market information put together derived data for ABR as follows; -

- Quantity demanded of 300 plants at a price of GH\$ 51.9 and

- Quantity supplied of 31 plants at same price of GH\$ 51.9

The ABR price was in thousands (000s) of Ghana cedis per plant.

The slope method combined the market data of the fixed dome and ABR technologies to derive the inverse demand and supply functions. The application of the slope method $\mathrm{P}=\mathrm{MQ}+\mathrm{C}$, gave among others, values of important variables of the inverse demand function as follows;

$$
M=\frac{68.89-51.9}{145-300}=-0.1096 ; \quad M Q=-0.1096(145)=-15.892
$$

$C=68.89+15.892=84.782 \cong 85$

By putting $\mathrm{M}$ and $\mathrm{C}$ into the market demand model of $\mathrm{P}=\mathrm{a}-\mathrm{d}(\mathrm{Q})$, the inverse demand function was derived as; $P=85-0.1096 Q$.

Similarly, in applying the slope method $\mathrm{P}=\mathrm{MQ}+\mathrm{C}$, important variables of the inverse supply function values among others were given as;

$Q=100 ; M=\frac{68.89-51.9}{100-31}=0.25 ; \quad M Q=25$, and $P=25+C$ 
Therefore; $C=68.89-25 \cong 44$. Putting $\mathrm{M}$ and $\mathrm{C}$ into the market supply model of $P=-c+b(Q)$ translated to the inverse supply function as; $P=44+0.25 Q$.

In equilibrium, the inverse demand and supply functions jointly derived the closure condition in equation five (5) as; $85-0.1 Q=44+0.25 Q$.

By formal treatment, equilibrium price and quantity were quantified as GH\& 73 and 117 units respectively.

\subsection{Direct benefit in 'free' biogas market}

This study quantified the consumer and producer surpluses for meaningful comparison. The equilibrium price and quantity together with the inverse demand function $P=85-0.1 Q$ and the inverse supply function $P=44+0.25 Q$ were built-in the Consumer Surplus (CS) and Producer Surplus (PS) integral equations;

$C S=\int_{0}^{Q} D Q d Q-P_{0} Q_{0}$, and $P S=P_{0} Q_{0}-\int_{0}^{Q} S Q d Q$. This conventional economic surplus measurement measured disaggregated direct benefits (consumer and producer surpluses) integrally and summed them up as social benefit as follows;-

$C S=\int_{0}^{117}(85-0.1 Q) d Q-(73 \times 117)=719.55$, and

$P S=(73 \times 117)-\int_{0}^{117}(85-0.1 Q) d Q=1681.88$

Net social welfare surplus per annum was obtained by adding CS and PS and dividing the result by 15yrs (2000-2015).

\subsection{Direct benefit in the regulated biogas market}

On regulated biogas market, this study presented a detailed procedure for direct benefits quantifications. The regulated market will represent the other extreme end of the market in the form of $2^{\text {nd }}$ and $3^{\text {rd }}$ degrees discriminating monopoly, based on output and markets respectively. Unlike in the free market where production efficiency is at where price is equal to marginal cost: $\mathrm{P}=\mathrm{MC}$, the other extreme end of the market which is represented by the regulated monopolist will produce at where marginal revenue is equal to marginal cost $\mathrm{MR}=\mathrm{MC}$. 
MR is obtained by differencing total revenue (TR) (which is price (P) multiplied by quantity (Q)) with respect to $Q$, where $T R=P Q=(a-d(Q)) Q$.

The inverse demand and supply functions were $P=85-0.1 Q$ and $44+0.25 Q$, respectively. Putting; $P=85-0.1 Q$, into TR and differentiating TR will give MR. Thus, $d T R / d Q=(a-d(Q)) Q / d Q=M R$, hence,

$M R=85-0.2 Q$

$M C=44+0.25 Q$

That is, MC is equal to the supply function. The monopolist will produce at where $\mathrm{MR}=\mathrm{MC}$. Hence, the equilibrium price and quantity for the monopolist were computed based on; $M R=M C=85-0.2 Q=44+$ $0.25 Q$.

The monopoly equilibrium price and quantity were $\mathrm{GH} \$ 67$ and $\mathrm{GH} 91$ units respectively. Evaluation of CS, PS and social benefit under monopoly given the inverse demand function of $85-0.2 \mathrm{Q}$ and MC of $44+0.25 \mathrm{Q}$, together with equilibrium price and quantity were as follows;

$$
\begin{gathered}
\left.C S=\int_{0}^{91}(85-0.2 Q) d Q-(91 \times 67)=85 Q-0.2 / 2 Q 2\right] 91-6097=810 . \\
P S=(91 \times 67)-\int_{0}^{91}(44+0.25 Q) d Q=6097-[44(91)+0.25 / 2 Q 2]=1058
\end{gathered}
$$

This evaluation will yield direct welfare benefit to consumers and producers. Deadweight Loss (DWL) reduced societal welfare. It is measured by $1 / 2$ (base * height)

$D W L=1 / 2\left(P_{1}-P_{0}\right)\left(Q_{0}-Q_{1}\right)$

Where $\mathrm{P}_{0}$ and $\mathrm{Q}_{0}$ are initial equilibrium price and quantity and $\mathrm{P}_{1}$ and $\mathrm{Q}_{1}$ are the new price and quantity respective, so $D W L=1 / 2(67-73)(117-91)=-78$. Note that you have to take the absolute value because dead weight loss can never be negative. DWL $=$ GH\$78(in 000s).

Indirect benefit in biogas business is mainly savings from slurry. The value of Cow dung organic fertilizer (premium) is an appropriate proxy to measure benefit (savings) from using biogas manure/slurry. The cost of cow dung organic fertilizer (premium) per 20kg bag was GH\$ 10.00 and usage was3650 bags in a year. 
Manufacture of slurry and gas expenses (Indirect cost). Operational and maintenance costs were incurred in respect of biogas plant attendants or cleaners, supervisor, casual labourers for minor jobs like weeding. Remuneration for these workers and the cost of water were evaluated. Two cleaners, one labourer and one security man provide operational services for the biogas plant at GH\$ 300.00 each per month. One technician was responsible for maintenance at $\mathrm{GH} \$ 500.00$ per month. The value of water used to prepare input slurry at less than 1\% of O\&M costs is insignificant (Purohit et al, 2007).In this study, water needed by one person in patronizing bio-toilet was 9 litres, approximately 2 gallons per day. For a population of 1000 , water requirement is two thousand (2000) gallons a day. Five hundred (500) gallons of water was sold at $\mathrm{GH} \$ 40,00$ and so the cost of 2000 gallons of water used in one day was $\mathrm{GH} \$ 160.00$. Annual estimate of water $=\mathrm{GH} \$ 58,400.00$.

Cost of maintenance and replacement of gas valves, lamp, cooking stove parts, fixing gas leakage points and other routine maintenance costs per annum had been shown by Kandpal et al. (1991), and Sinha and Kandpal, 1990) as estimate of $4 \%$ the capital cost of the plant. Hence cost of maintenance and replacement is estimated at $4 \%$ of $\mathrm{GH} \$ 78,445.00$. Expenditure on menial jobs, hygienic tools and materials and transportation of sawdust etc. are sundry expenses which were estimated at $\mathrm{GH} \$ 8,030.00$. The per annum values of net social benefit, indirect benefit and flow of benefit have been shown in Table 1.

Table 1;

Quantified benefits in the two markets

\begin{tabular}{llrr}
\hline No & \multicolumn{1}{c}{ Description of Benefits } & $\begin{array}{c}\text { Free Biogas } \\
\text { Market GH } \phi\end{array}$ & $\begin{array}{c}\text { Regulated } \\
\text { Monopoly } \\
\text { market GH } \phi\end{array}$ \\
\hline 1 & CS & $719,550.00$ & $810,000.00$ \\
2 & PS & $1,681,875.00$ & $1,058,000.00$ \\
3 & Net Social benefit for 15yrs (1+2) & $2,401,425.00$ & $1,868,000.00$ \\
& Net social benefit per annum & $160,095.00$ & $124,533.33$ \\
5 & Indirect benefit per annum & $36,500.00$ & $36,500.00$ \\
6 & Total Flow of benefit per annum (4+5) & $196,595.00$ & $161,033.33$ \\
\hline
\end{tabular}

Source: Market benefits analysis

The annual flow of benefit, research costs and the discount rate were necessary for investment appraisal techniques such as NPV, IRR, BCR or PI and payback period.

Ascertained direct cost; Costs included all the expenditure on assets and wages. Assets or capital used in biogas construction included land, digester, accessories and systems. The breakdown of Total direct costs found in CSIR-IIR biogas proposal budget of GH\$ 78,445.00is as follows; - The pre-constructional stage 
cost of GH\$ 6,480.00; constructional stage amounted to $\mathrm{GH} \$ 30,418.00$ and post-constructional expenditures of $\mathrm{GH} \$ 41,547.00$

In other to ascertain whether regulated monopoly market ensures widespread and higher welfare gains, its values for CS, PS, Net Social benefit per annum and Flow of benefit per annum found in this study were compared with the same values from the free biogas market. The strength of the meaningful results was attributed to the same source data and methods that enabled uniform analysis except the different efficiency conditions. Table 2 shows the Summary of costs and benefits in GH\$ before conversion into US\$.

Table 2;

Summary of costs and benefits in GH\$ before conversion into US\$

\begin{tabular}{clrr}
\hline No & \multicolumn{1}{c}{ Description } & $\begin{array}{c}\text { Free Market } \\
\text { GH } \boldsymbol{\phi}\end{array}$ & $\begin{array}{c}\text { Regulated } \\
\text { Monopoly } \\
\text { Market GH } \boldsymbol{\phi}\end{array}$ \\
\hline 1 & Total cost & $154,912.00$ & $154,912.00$ \\
2 & Total Flow of benefit per annum & $196,595.00$ & $161,033.33$ \\
3 & Total indirect cost & $75,905.41$ & $75,905.41$ \\
4 & Flow of net benefit per annum 2-3 & $120,689.59$ & $85,127.92$ \\
\hline Source: Market net benefit analysis & &
\end{tabular}

\subsection{Results and Discussions}

The study of Bensah et al., (2010), and other biogas studies in Ghana did not produce economic viability results. This study focuses on relative decreases or increases in Consumer Surplus (CS), Producer Surplus (PS), social surplus and NPV in the two biogas markets.

In Table 1, in spite of the so-called inefficiencies of neoclassical monopoly, regulated monopoly performances in Consumer Surplus (CS), Producer Surplus (PS) and social surplus were considerably high and positive although PS is below the value observed for free market.

The high benefits (Consumer Surplus, Producer Surplus and social surplus) in free biogas market recorded in this study directly collates with the profitability of family sized digesters in Uganda by (Walekhwa 2010). The value of Consumer Surplus (CS) in regulated market increased over and above the CS value in free market by 12.57 approximately $13 \%$. 
The explanation for the inability of the regulatory monopolist to shift part of consumer surplus to producer surplus can be found in Stamate, (2011) on the fundamental law of demand and supply. This law provides that price reduction corresponds with increase in quantity demanded, and all other things being equal this will maximize benefit. This limited the power of the regulated monopolist, Costea, (2006, pp. 75). So the consumers who contrary to the neoclassical theory, supposed to be hurt by the actions of monopoly, actually gained by their decision to pay equilibrium price in this study.

However, the argument of Stamate, (2011), meant that the regulated monopolist ego to charge higher price diminished by market forces. This from the point of view of this study led to popularisation of biogas technology that allowed schools, abattoirs and others to become customers in biogas market, in addition to, traditional biogas dissemination to communities. This underlies the long term strength of the market forces to curtail monopoly supernormal/abnormal benefit arising out of higher price charge. It is therefore not a fluke to observe the loss of 37.09 approximately $37 \%$ in producer surplus in this study.

A real example of producer loss in a regulated market is the ridiculously low professional fees received by CSIR-IIR as a producer of biogas in the National Biogas Project. In the view of this study, what also might have occasioned such a loss in producer surplus is that in government projects there is a tacit demand on government to reward special interests against 'public interest'. This affected CSIR-IIR benefit in the regulated monopoly market irrespective of price and output discrimination, and so subjecting the market participants (including CSIR-IIR) in the National Biogas Project to the universal economic laws concerning market forces.

The arrangement in government biogas projects where CSIR-IIR designs and supervises construction of biogas for professional fees, whereas private companies get paid for undertaking construction of biogas under Public Private Partnership (PPP), is most likely, not to incur higher prices and so secure benefits of all biogas participants.

However, enormous benefit can be realised from biogas contracts. In Rothbard, (2004) and Stamate, (2009) it was argued that in markets where demand exists, people could sell goods on a contractual basis; and so it is not a crime when one person gains and the other lose. The diffusion of biogas to households (previously not accepting biogas) and consumers such as hotels, hospitals, Senior High Schools and communities can be done on contract and subcontract basis. In this scenario, the tendency to charge higher price is avoided even now and in future. 
From the integral analysis and the discussions, the loss in producer surplus outweighed the gain in consumer surplus, and the net effect of this is a reduction in social benefit of 22.21 approximately $22 \%$. The regulated monopoly market redistributed benefit by the gain in consumer surplus and the loss in producer surplus and social benefit including the deadweight loss. Conversion of the deadweight loss given an exchange rate of US\$ $1=$ GH\$ 4.3 will amount to US\$ 18,139.53 approximately US\$ 18,140.00. This constitutes the distributional inefficiency of regulated market (monopoly).

The last financial indicator is for owners of capital or investors. Table 3 shows the conversion of the costs and benefits and the results of the investment techniques, at the exchange rate of US\$ $1=\mathrm{GH} \$ 4.3$ and a discount rate (r) of 22\%. Present Value Annuity Table for $\$ 1$ paid in each of the 20 periods at $22 \%=4.460$ this was applied to the stream of equal flow of benefit.

Table 3;

Investment appraisal results

\begin{tabular}{|c|c|c|c|}
\hline No. & Description & Free Market & $\begin{array}{c}\text { Regulated } \\
\text { Monopoly market }\end{array}$ \\
\hline 1. & Total cost & US\$ $36,026.05$ & US\$ 36,026.05 \\
\hline 2. & Flow of net benefit per annum & US $\$ 28,067.00$ & US\$19,797.19 \\
\hline 3. & Total indirect cost & US\$17,652.42 & US\$17652.42 \\
\hline 4. & Total annual profit $2-3$ & US $\$ 10,414.52$ & US\$2,144.77 \\
\hline 5. & Payback Period 1/ 4 & 3.46 & 16.79 \\
\hline 6. & PV $(2 * 4.460)$ & US $\$ 125,178.82$ & US $\$ 88,295.46$ \\
\hline 7. & NPV 6-1 & US\$89,152.75 & US\$52,269.41 \\
\hline 8. & $\operatorname{IRR}\left(\mathrm{r}^{*}\right)$ & $77.80 \%$ & \\
\hline 9. & PI 6/1 & 3.4746 & 1.458 \\
\hline
\end{tabular}

Source: Investor's information analysis

NPVs for both markets were positive (NPV >0), which implies that the rate of returns on investment into biogas was higher than the discount rate used and were greater than the opportunity cost of capital used at the discount rate. This confirmed the posited benefits of biogas. However, investors' NPVwill be worse of under a regulated monopoly by approximately $41 \%$. This means that there is also a loss of benefit due investors under a regulated monopoly.

\subsection{Conclusion and Recommendation}


Loss in PS, NPV and deadweight loss all under regulated monopoly market structure as compared with 'free' market is an indication that regulated markets subtract from societal gains. Comparing consumer gain of $13 \%$ for the regulated monopolist at one hand, a loss of $37 \%$ by the producers, a loss of $41 \%$ to investors in NPV and deadweight loss of US\$18,140.00, suggests an indictment though not incriminating on the part of regulated monopoly market. Market forces allow the decision of consumers to regulate future monopoly power especially in government regulated $2^{\text {nd }}$ and $3^{\text {rd }}$ degree monopoly market. The popularisation of biogas technology creates new and numerous customers in biogas market. In line with laws of demand, decision by customers to reduce quantity demanded as a result of higher price charge by regulated monopoly will undermine monopoly power. The study recommends public and private companies roles under PPP, must be well defined and adhere to in biogas contract and sub-contract basis.

\section{Reference}

1. Abbasi, T., Tauseef, S. M. \& Abbasi, S. A., (2012) Anaerobic Digestion for Global Warming Control and Energy Generation-An Overview. Renewable and Sustainable Energy Reviews, Volume 16, p. 3228- 3242.

2. Ankamah, E. F., Dzamboe, P. D., Agbedor, P. M., Tottimeh, G., Amoah, J. Y., (2017) Techno-economics of Biochar and Biogas viability in Ghana, International Journal of Technology and Management Research, Volume 2. Number 3: 33- 41 (2017)

3. Bensah, E. C., Brew-Hammond, A., (2010) Biogas Technology Dissemination in Ghana: History, Current status, Future prospects, and Policy significance International Journal of Energy and Environment Volume 1, Issue 2, pp.277-294

4. Herrmann, C., Idler, C.M Heiermann, M., (2016) Biogas Crops Grown in Energy Crop Rotations: Linking Chemical Composition and Methane Production Characteristics. Bioresource Technology, Volume 206, pp. 23-35.

5. Maredia, K. M., Byerlee, D., Anderson J. R., (2000) Ex Post Evaluation of Economic Impacts of Agricultural Research Programs: A Tour of Good Practice.

6. Masters, W., Coulibaly, B., Sanogo, D.,Sidibé, M., Williams, A.,(1996) The Economic Impact of Agricultural Research: A Practical Guide. Department of Agricultural Economics, Purdue University, West Lafayette, IN

7. Kandpal C., Bharati, J., Sinha, C. S., (1991) Economics of Family sized Biogas Plants in India. Energy Conversation Management 32, 101-113. 
8. Sinha C. S., Kandpal, C., (1990) A framework for the Financial Evaluation of Household BiogasPlants in India, Biomass 23, 39 - 53

9. Purohit, P., Kandpal, T. C., (2007) Techno-economics of biogas-based water pumping in India: An attempt to internalize CO2 emissions mitigation and other economic benefits, Renewable and Sustainable Energy Reviews 11, 1208-1226.

10. Costea, D. (2006) Activitatea antreprenorială și problema echilibrului economic înviziunea Școlii Austriece, $\mathrm{PhD}$ Thesis, Bucharest Academy of Economic Studies rk

11. Rothbard M. N., (2004) Man, economy and state with Power and Market, The Scholar'sedition, Auburn, Alabama: The Ludwig von Mises Institute, Second edition

12. Salerno J. T., (2005) Theory of Monopoly Price: From Menger to Rothbard, at the Austrian School of Economics: Revisionist History and Contemporary Theory seminar on June 7th, Ludwig von Mises Institute, Auburn, Alabama

13. Stamate, A., (2011), An Economic Interpretation of Neoclassical MonopolyTheory In The Light of Austrian School

14. Stamate, A., (2009) Teoria austriacă post-misesiană a monopolului: Murray NewtonRothbard, Revista Oeconomica - Societatea Română de Economie (SOREC) - InstitutulRomân pentru Libera Întreprindere, Anul XVIII, nr.1

15. Wagner, A. O., Malin, C., Gstraunthaler, G. \& Illmer, P., (2009) Survival of Selected PathogensinDiluted Sludge of a Thermophilic Waste Treatment Plant and in $\mathrm{NaCl}$-solution under Aerobic and Anaerobic Conditions. Waste Management, Volume 29, p. 425-429.

16. Walekhwa, P. N., 2010. Socio-economic assessment of biogas production and utilization in Uganda http://hdl.handle.net/10570/2173

17. Yiridoe, E. K. Gordon, R. Brown, B. B. (2009) Nonmarket co-benefits and economic feasibility of on-farm biogas energy production. Energy Policy 37, 1170-1179. 